UDC 542.973

\author{
V.A. Vekshyn ${ }^{a}$, E.R. Grabovetskaya ${ }^{b}$, L.P. Abramova ${ }^{a}$
}

\title{
TECHNICAL CHARACTERISTICS OF A CELLULAR CATALYST FOR THE REDUCTION OF NITROGEN (II) AND (IV) OXIDES AND DESIGN OF A SUITABLE REACTOR
}

\author{
${ }^{a}$ Kharkiv National Medical University, Kharkiv, Ukraine \\ ${ }^{b}$ V.N. Karazin Kharkiv National University, Kharkiv, Ukraine
}

\begin{abstract}
The method of the designing of industrial reactors with metal cellular catalysts is considered in the article. The proposed catalysts can be used for the low-temperature purification of exhaust gases from nitrogen oxides using ammonia. The advantages of catalytic blocks are shown in comparison with the catalysts AVC-10 that is widely used in industry. The procedures of physicochemical study and analytical control are developed. Based on laboratory tests, the sizes and structure of the proposed reactors are determined. Required amount of catalyst in the form of metal cellular blocks is determined for two types of reactors: with rectangular and circular cross-sections. The length of catalytic units is calculated and production technology is proposed. Hydrodynamic calculations demonstrate that block catalysts have lower flow resistance that the granulated ones. The reactors of circular cross-section need catalytic units of smaller volume than rectangular ones; however, the latter have a lower resistance to gas flow. The study shows that the metal cellular catalytic blocks would allow avoiding the use of additional compressors for excessive pressure to purge gases through the catalyst bed, which should reduce economic costs, and, ultimately, reduce the cost of the product.
\end{abstract}

Keywords: oxide, carrier, catalyst, reactor, purification, nitrogen, structure.

DOI: $10.32434 / 0321-4095-2019-127-6-24-30$

\section{Introduction}

The process of nitric acid production is accompanied by the formation of residues of toxic nitrogen oxides as a mixture of $\mathrm{NO}$ and $\mathrm{NO}_{2}$ which must be disposed. At nitric acid plants, this process is carried out using low-temperature reduction with ammonia on the aluminum vanadium catalyst AVC10. The main disadvantage of this scheme is an excessive resistance to the gas flow due to the layer of a granular catalyst. This complicates the highquality purification under conditions of high volumetric rate of gases.

This issue may be solved by the replacement of granulated AVC-10 catalyst by metal block catalysts of a cellular structure. Such systems have a number of significant advantages, namely: metal blocks are easy to produce; they have higher mechanical strength and thermal conductivity, and show enhanced resistant to rapid changes of temperature. The use of metal blocks allows reducing the contact time up to a few milliseconds and adjusting the temperature of the system almost instantly. The ability to quickly vary the temperature regime is extremely important to control unwanted adverse reactions. Block catalysts differ from granular ones in terms of high porosity, and their catalytic layer cannot be damaged. Application of blocks provides a more efficient use of the surface. The mass of reactors with such carriers is significantly low, and ease of loading. The absence of dust and the possibility of regeneration indicate that block reactors are more promising than modern industrial reactors.

The preparation of catalysts concerned is based on coating methods that combine high uniformity of the obtained layer with technological simplicity, the possibility of applying a small amount of the active component and high activity [1,2]. The MOM (metal-oxide-metal) system is an example of such a catalyst. From technological point of view, this system is a titanium carrier covered with a porous oxide coating formed by means of electrochemical anodization. The active substance in the form of

(C) V.A. Vekshyn, E.R. Grabovetskaya, L.P. Abramova, 2019 
platinum is deposited on the $\mathrm{TiO}_{2}$ surface from a water-soluble complex $\mathrm{H}_{2}\left[\mathrm{PtCl}_{6}\right]$. For platinum reduction and highly dispersed Pt-black preparation, the carrier is additionally modified with formic acid [3].

\section{Experimental, results and discussion}

Pilot tests for the reduction of $\mathrm{NO}_{x}$ in the exhaust gas were carried out using a flow-type quartz reactor (Fig. 1). The laboratory reactor consists of a reactor vessel 1 hermetically sealed by a lid 2 . The lid provides loading of a catalyst plate 4 into a reaction zone 3 . The studies were conducted on a catalyst plate of size $10 \mathrm{~cm} \times 2 \mathrm{~cm} \times 0.2 \mathrm{~cm}$ with a catalytic layer length of $8 \mathrm{~cm}$. To ensure the required temperature regime, the reactor was installed in a tube furnace, which is not shown in the Fig. 1. The exhaust gas $\left(\approx 0.12 \% \quad \mathrm{NO}_{\mathrm{x}}\right)$ was delivered into the tube 7 , heated to the operating temperature in the coil 5 and entered from the bottom up into the reaction zone through the opening 6 . Ammonia was blown downward through the tube 8 which was long enough to deliver reducing agent directly into the reaction zone. Technical holes 9 and 10 were used for gas extraction for analysis.

The temperature was controlled by means of a thermocouple, the flow rate of the reacting gases was maintained based on the measurements performed by rheometers. Gas was extracted by means of vacuum vessels. Gas analysis was carried out by specified photocolorimetry. Activity tests showed that the catalyst reduction was equal to $96.5 \%$, which means that it can be used for the production of purification system.

Industrial catalyst is a cassette made of

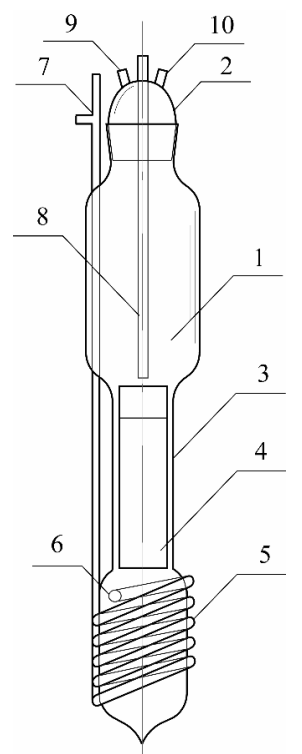

Fig. 1. Diagram of the reactor for laboratory research corrugated and anodized titanium plates coated with a catalytically active substance. This is the way of common catalytic block formation. The tape from the roll enters the roll-forming machine where it is corrugated, and then the prepared plate is cut with a guillotine up to the desired size. Two corrugated plates form a set of components through which the gas mixture passes. Next, the plate is subjected to anodizing, coated with a catalytically active substance, and collected in the block. The plates are fixed by welding in the points of corrugations contact. After that, the block is wrapped in a titanium sheet of the required length from a roll of $800 \mathrm{~mm} \times 1 \mathrm{~mm}$ in size and fixed by welding [4].

The parameters of industrial purification reactor were calculated based on laboratory data taking the flow rate of exhaust gas under the conditions of $\mathrm{HNO}_{3}$ production $\left(50,000 \mathrm{~m}^{3}\right.$ hour $\left.^{-1}\right)$.

The linear gas velocity for each volumetric flow rate was determined according to preliminary experimental study. The volume of the reactor was derived from the formula (1):

$$
\tau=\frac{\mathrm{V}_{\mathrm{r}} \cdot \eta}{\mathrm{V}_{\mathrm{g}}}
$$

where $V_{r}$ is the volume of reaction zone $\left(\mathrm{m}^{3}\right)$; and $\mathrm{V}_{\mathrm{g}}$ is the gas flow rate $\left(\mathrm{m}^{3}\right.$ hour $\left.\mathrm{r}^{-1}\right)$;

The cross-section area was found based on the formula (2) considering the industrial gas flow $\left(\approx 14 \mathrm{~m}^{3} \mathrm{~s}^{-1}\right)$ :

$\mathrm{W}=\frac{\mathrm{Q}_{\mathrm{g}}}{\mathrm{F}}$,

where $\mathrm{w}$ is the gas linear velocity in a pipeline $\left(\mathrm{m} \mathrm{s}^{-1}\right)$; $\mathrm{Q}_{\mathrm{g}}$ is the gas volume flow rate under flow conditions $\left(\mathrm{m}^{3} \mathrm{~s}^{-1}\right)$; and $\mathrm{F}$ is the cross-section area of the flow (pipe) $\left(\mathrm{m}^{2}\right)$.

The results of calculation are given in Table 1 .

The reactor is a block-containing cassette with a required number of prepared titanium plates coated with catalytic substance. The following calculations were used to determine the distance between the plates (5):

$-\frac{\mathrm{dC}}{\mathrm{d} \tau}=\frac{\mathrm{k}^{\prime} \cdot \mathrm{D}}{\mathrm{D}+\mathrm{k}^{\prime} \cdot \delta} \cdot \mathrm{F} \cdot\left(\mathrm{C}_{\mathrm{\Pi}}-\mathrm{C}_{\mathrm{p}}^{*}\right)$,

or if $\mathrm{r}$ stands for the reaction rate:

$-\frac{d C}{d \tau}=r=\frac{k^{\prime} \cdot D \cdot F \cdot\left(C_{n}-C_{p}^{*}\right)}{D+k^{\prime} \cdot \delta}$. 
Table 1

Calculation results for an industrial reactor

\begin{tabular}{c|c|c|c|c|c}
\hline $\begin{array}{c}\text { Volumetric flow } \\
\text { rate, hour }^{-1}\end{array}$ & $\begin{array}{c}\text { Contact time, } \\
\tau, \mathrm{s}\end{array}$ & $\begin{array}{c}\text { Gas flow rate, } \\
\mathrm{V}_{\mathrm{g}}, \mathrm{m}^{3} \mathrm{~s}^{-1}\end{array}$ & $\begin{array}{c}\text { Reactor volume } \\
\mathrm{V}_{\mathrm{r}}, \mathrm{m}^{3}\end{array}$ & $\begin{array}{c}\text { Linear velocity, } \\
\mathrm{w}, \mathrm{m} \mathrm{s}^{-1}\end{array}$ & $\begin{array}{c}\text { Cross-section area c } \\
\text { reactor, } \mathrm{F}, \mathrm{m}^{2}\end{array}$ \\
\hline 15000 & 0.12 & 14 & 3.36 & 4.38 & 3.2 \\
\hline 10000 & 0.18 & 14 & 5.04 & 2.81 & 4.98 \\
\hline 5000 & 0.36 & 14 & 10.08 & 1.35 & 10.34 \\
\hline
\end{tabular}

The size of interface can be found as:

$\delta=\frac{\left(\mathrm{k}^{\prime} \cdot \mathrm{D} \cdot \mathrm{F} \cdot\left(\mathrm{C}_{\mathrm{n}}-\mathrm{C}_{\mathrm{p}}^{*}\right) \cdot \frac{1}{\mathrm{r}}\right)-\mathrm{D}}{\mathrm{k}^{\prime}}$,

where $\mathrm{k}^{\prime}$ is the calculated reaction rate constant $\left(\mathrm{s}^{-1}\right)$; D is the molecular diffusion coefficient $\left(\mathrm{cm}^{2} \mathrm{~s}^{-1}\right) ; \delta$ is the distance from the catalyst wall to the middle $(\mathrm{cm}) ; \mathrm{F}$ is the calculated surface area $\left(\mathrm{cm}^{2}\right) ; \mathrm{C}_{\mathrm{n}}{ }^{*}$ is the initial concentration of $\mathrm{NO}_{x}$ $\left(\mathrm{mol} \mathrm{L}^{-1}\right)$; and $\mathrm{C}_{\mathrm{p}}{ }^{*}$ is the equilibrium concentration of $\mathrm{NO}_{\mathrm{x}}$.

The distance between the plates is taken as a double value of the interface, that is, $\delta^{\prime}=2 \times \delta$. The calculations showed that the optimal distance between the plates was $6 \mathrm{~mm}$.

Based on the obtained data, the parameters of the reactor were calculated, previously assuming that the cross section of the reactor was square. The calculation results show that the optimal size of the reactor, which can provide a contact time of about $0.12-0.18 \mathrm{~s}$ in production, is $2.23 \mathrm{~m} \times 2.23 \mathrm{~m} \times 1.01 \mathrm{~m}$. The design features of the catalyst should be taken into account (size, shape and volume) and its location in the device. In this case, the following form is proposed: titanium rolled sheets with a standard size of $1000 \mathrm{~mm} \times 2000 \mathrm{~mm} \times 1 \mathrm{~mm}$, corrugated at an angle of $90^{\circ}$ on the larger side. After corrugation, the plate sizes are $1000 \mathrm{~mm} \times 1430 \mathrm{~mm} \times 5.25 \mathrm{~mm}$. The prepared sheets are laid in the reactor in such a way as the triangles of two corrugations form one reactor unit of square section. The number of these components (i.e., reactor units) depends on the number of plates, the length and the width of the reactor, but its height is always constant and equals to $1 \mathrm{~m}$. Thus, catalytic tunnels are constructed from two corrugated plates, and the thickness of one block is the sum of the thickness of two corrugated plates, which is $10.5 \mathrm{~mm}$ (Fig. 2).

The following equation was used to determine the length of the catalytic plate:

$\omega \cdot \frac{\mathrm{dx}}{\mathrm{dl}_{\mathrm{p}}}=\mathrm{k} \cdot \mathrm{F} \cdot(1-\mathrm{x})$.

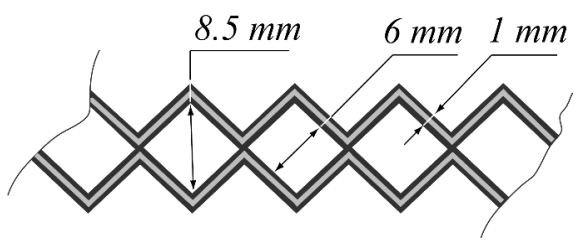

Fig. 2. Arrangement of catalyst sheets in the reactor

Taking integral of equation (6), the following equation was obtained:

$\int_{0}^{1} \mathrm{~d} l_{\mathrm{p}}=\int_{0}^{1} \frac{\omega}{\mathrm{k} \cdot \mathrm{F}} \cdot \int_{0}^{1} \frac{\mathrm{dx}}{1-\mathrm{x}}$.

The solution of the equation coupling the surface area with number of the plates is as follows:

$1_{p}=\frac{-\omega \cdot \ln (1-x)}{k \cdot n \cdot F}$

where $\omega$ is the gas flow rate $\left(\mathrm{cm}^{3} \mathrm{~s}^{-1}\right)$; $\mathrm{k}$ is the reaction rate constant per surface unit $\left(\mathrm{m}^{2} \mathrm{~s}^{-1}\right)$; F is the surface area $\left(\mathrm{cm}^{2} \mathrm{~g}^{-1}\right)$; $\mathrm{x}$ is the degree of reduction (fr. unit); $1_{p}$ is the length of plate $(\mathrm{cm})$; and $n$ is the number of plates.

Using the above formula, two parameters can be defined, namely the plate length $1_{p}$ and the number of plates $n$, but it must be borne in mind that the reactor is planned to be used under actual production conditions; therefore its parameters must strictly follow the requirements for industrial reactors. These requirements include the following issues: maximum productivity and intensity of work; high yield and the highest selectivity of the process ensured by the optimal mode of operation of the reactor (temperature, pressure, concentration of the initial substances and effective use of the catalyst); minimal energy costs for mixing and transporting substances through the reactor; optimal use of energy of exothermic reactions or heat supplied to the reactor for heating the reacting substances; easy operation and safety of work ensured by the design of the reactor and small fluctuations in the technological mode; low cost of manufacture of the reactor and ease of 
repair; and stability of operation of the device in case of significant alterations in the main parameters of the regime (concentration, temperature, etc.). In view of the above, calculations of the reactor parameters were mostly based on experimental data, and idealized models were used to apply the results fully.

When calculating the reactor parameters, the maximum contact time was taken as $0.18 \mathrm{~s}$, which corresponds to a gas flow rate of $10,000 \mathrm{~h}^{-1}$. The calculation was performed according to the estimated reactor volume of $5.04 \mathrm{~m}^{3}$ and cross-section of $4.98 \mathrm{~m}^{2}$. Calculations have shown that maximum cleaning efficiency with a gas flow rate of $50,000 \mathrm{~m}^{3} \mathrm{~h}^{-1}$ can be provided by reactor with the following parameters: width of $1.43 \mathrm{~m}$; length of 3.52; and height of $1 \mathrm{~m}$. The reactor in the reaction zone contains 670 corrugated plates of size $1000 \mathrm{~mm} \times 1430$ (corrugated) $\mathrm{mm} \times 1 \mathrm{~mm}$. Thus, by carrying out corresponding calculations based on a square reactor, we obtained a rectangular reactor. Its construction is shown in Fig. 3.

The reactor consists of a rectangular reactor vessel 1 , which contains a metal catalyst block 7 . There is a heating zone 6 between the reactor vessel and the catalyst. The hot steam is fed into heating zone 6 through holes 5 . Below the reactor, there is a bottom 10, which has the holes: 8 - for nitrogen oxides; and 9 - for ammonia. Reacting substances are mixed in the volume of the bottom 10 and are fed into the reaction zone heated up to the process temperature, where catalyst 7 is installed. The gas mixture passes through the catalyst bed, reacts with the formation of nitrogen and water which passing through the opening 3 , located at the top of lid 2, are released into the atmosphere.

Considering the possibility of stagnant zones formation in a rectangular reactor, and in order to bring the process equipment to a standard type, the parameters of a circular catalytic reactor were also calculated based on common initial data and those obtained for a rectangular reactor. Thus, the dimensions of the previous reactor were taken as the basis for determining the diameter of the apparatus, followed by conversion to an equivalent diameter using the following formula:

$d_{e}=\frac{2 \cdot a \cdot b}{a+b}=\frac{2 \cdot 1.43 \cdot 3.52}{1.43+3.52}=2 \mathrm{~m}$,

where $a$ and $b$ are the sides of the pipes of the reactor units $(\mathrm{m})$.

The height of the reactor was calculated in such a way as to make its volume capable to provide efficient operation under the conditions of industrial exhaust gas flow $\left(50,000 \mathrm{~m}^{3} \mathrm{~h}^{-1}\right)$. The calculations results allowed us to determine the following dimensions of the reactor catalytic region: diameter $\varnothing=2 \mathrm{~m}$, and height $\mathrm{h}=1.6 \mathrm{~m}$.

The reactor consists of a cylindrical shell with a conical lid on the one side and bottom on the other. The reaction zone is filled with corrugated plates from the center of the reactor to its walls. Because of circular cross-section of the reactor, the size of each subsequent plate will be different from the previous one. The change in the length of the

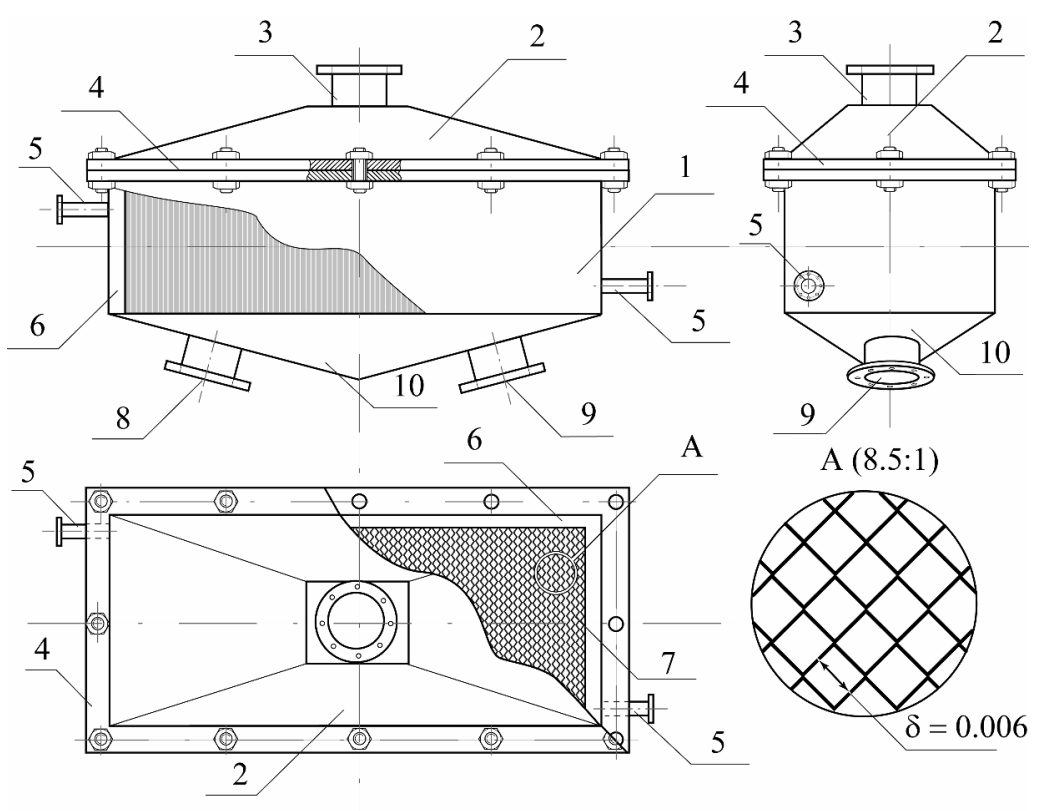

Fig. 3. Design of the rectangular-type purification reactor 
plates from the center to the periphery can be calculated by the following formula:

$$
1_{d}=2 \sqrt{\mathrm{R}^{2}-1_{d}^{2}},
$$

where $\mathrm{R}$ is the radius of reactor; and $l_{\mathrm{d}}$ is the distance from the center to the periphery.

$$
1_{\mathrm{d}}=\mathrm{n} \cdot \mathrm{l}^{\prime}-\mathrm{l}^{\prime},
$$

where $\mathrm{n}$ is the number of plates starting from the center; and l' is the plate thickness.

The solution of these equations allowed us to determine the required number of plates: 382 pcs. Thus, the plate metal catalyst for a circular reactor is proposed to be manufactured from titanium roll with a thickness of $1 \mathrm{~mm}$ and a width of $800 \mathrm{~mm}$. The calculations showed that $427 \mathrm{~m}$ of titanium tape of $0.8 \mathrm{~m}$ wide and $0.001 \mathrm{~m}$ thick was needed for one catalyst unit: $420.3 \mathrm{~m}$ for a titanium catalyst manufacturing and $6.3 \mathrm{~m}$ for bonding plates with a shell.

As the length of the reactor is $1.6 \mathrm{~m}$, two blocks should be installed one above the other. The design of the cylindrical reactor is shown in Fig. 4.

The reactor consists of a vessel 1 , which contains a metal catalyst block 7 . There is a heating zone 6 between the reactor vessel and the catalyst. The hot steam is fed into heating zone 6 through holes 5 . Below the reactor, there is the conical bottom 10, which has the ducts: 8 - for nitrogen oxides; and $9-$ for ammonia. Reacting substances are mixed in the volume of the conical bottom and are fed into

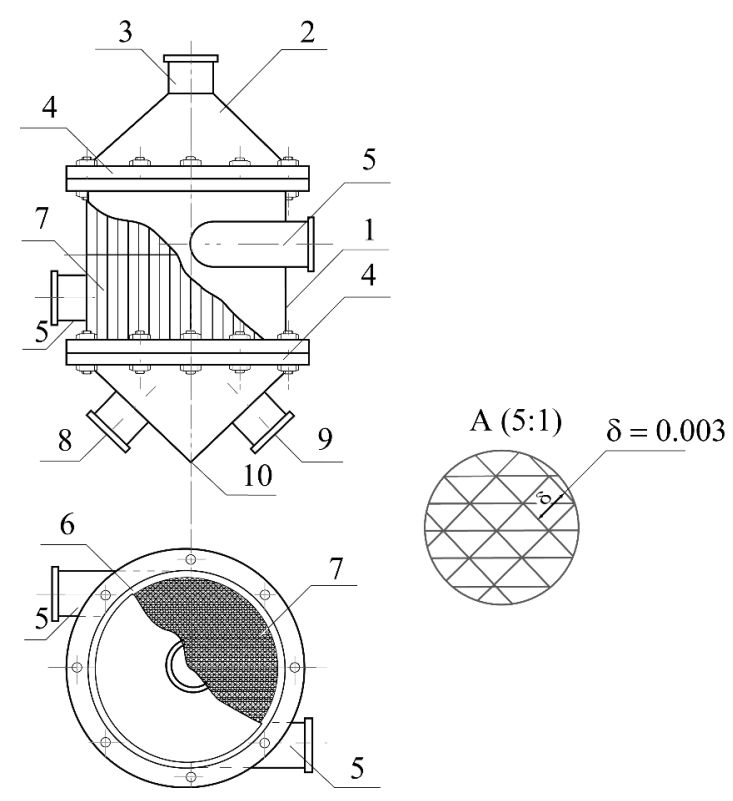

Fig. 4. Design of the cylindrical reactor the heated reaction zone, where catalyst 7 is installed. The gas mixture reacts with the formation of nitrogen and water and releases into the atmosphere through the opening 3, located at the top of lid 2.

Offering two types of reactors, rectangular and cylindrical ones, we calculated the number of pipes: reactor units for each of them, by applying the formula (11). At the same time, calculations strictly depended on the constant parameters: flow rate of gas mixture, volumetric flow rate, and, accordingly, the contact time, and reaction rate constant. The results are shown in Table 2.

\section{Required number of reactor units (pipes)}

\begin{tabular}{c|c|c|c|c}
\hline $\begin{array}{c}\text { Reactor } \\
\text { design }\end{array}$ & $\begin{array}{c}\text { Gas flow } \\
\text { rate, w, } \\
\mathrm{cm}^{3} \mathrm{~s}^{-1}\end{array}$ & $\begin{array}{c}\text { Plate } \\
\text { length, } \\
1, \mathrm{~cm}\end{array}$ & $\begin{array}{c}\text { Surface area } \\
\text { of one side, } \\
\mathrm{F}, \mathrm{cm}^{2}\end{array}$ & $\begin{array}{c}\text { Number } \\
\text { of pipes, } \\
\mathrm{n}, \mathrm{pcs}\end{array}$ \\
\hline Rectangular & $1.4 \cdot 10^{7}$ & 100 & 60 & 26209 \\
\hline Cylindrical & $1.4 \cdot 10^{7}$ & 160 & 96 & 16380 \\
\hline
\end{tabular}

The actual number of reactor units was determined according to the accepted reactor models: for a rectangular reactor - by the number of plates, and for a cylindrical reactor - according to formula (11). The results are shown in Table 3.

Table 3

Actual number of reactor units

\begin{tabular}{c|c|c|c}
\hline $\begin{array}{c}\text { Reactor } \\
\text { design }\end{array}$ & $\begin{array}{c}\text { Total required } \\
\text { number of } \\
\text { reactor units, } \\
\text { pcs }\end{array}$ & $\begin{array}{c}\text { Actual number } \\
\text { of reactor } \\
\text { units, pcs }\end{array}$ & $\begin{array}{c}\text { Variance } \\
\text { percentage, } \\
\%\end{array}$ \\
\hline Rectangular & 26209 & 27917 & +6.12 \\
\hline Cylindrical & 16380 & 17512 & +6.90 \\
\hline
\end{tabular}

The data show that the number of actual reactor units exceeds the calculated required number by more than $6 \%$, which can be regarded as a reserve.

The flow resistance of the developed catalyst was calculated by the Darcy-Weisbach formula [7] in pressure units:

$\Delta \mathrm{P}=\lambda \cdot \frac{1 \cdot \rho \cdot \mathrm{w}^{2}}{\mathrm{~d}_{\mathrm{e}} \cdot 2 \cdot \mathrm{g}}$,

where $\lambda$ is the flow coefficient (Darcy friction factor); 1 is the pipe length $(\mathrm{m}) ; \mathrm{d}_{\mathrm{e}}$ is the hydraulic diameter $(\mathrm{m}) ; \mathrm{r}$ is the medium density $\left(\mathrm{g} \mathrm{L}^{-1}\right)$; $\mathrm{w}$ is the linear velocity $\left(\mathrm{m} \mathrm{s}^{-1}\right)$; and $\mathrm{g}$ is the acceleration of gravity $\left(\mathrm{m} \mathrm{s}^{-2}\right)$.

The hydraulic diameter of pipes with noncircular cross section was found by the formula (9). 
Flow resistance of the developed reactors as compared to the industrial reactors with AVC catalyst

\begin{tabular}{l|c|c|c|c|c}
\hline Type of reactor & $\begin{array}{c}\text { Darcy friction factor, } \\
\lambda\end{array}$ & $\begin{array}{c}\text { Pipe length, } \\
1, \mathrm{~m}\end{array}$ & $\begin{array}{c}\text { Hydraulic diameter, } \\
\mathrm{d}, \mathrm{m}\end{array}$ & $\begin{array}{c}\text { Linear velocity, } \\
\mathrm{w}, \mathrm{m} \mathrm{s}^{-1}\end{array}$ & $\Delta \mathrm{P}, \mathrm{MPa} \mathrm{m}_{\text {layer }}{ }^{-1}$ \\
\hline Rectangular reactor & 0.09 & 1.0 & 0.006 & 4.4 & $9.81 \cdot 10^{-5}$ \\
\hline Cylindrical reactor & 0.09 & 1.6 & 0.006 & 4.4 & $1.92 \cdot 10^{-4}$ \\
\hline Industrial reactor & 12.67 & 0.8 & 0.006 & 2.8 & $2.3 \cdot 10^{-3}$ \\
\hline
\end{tabular}

It equals to $0.006 \mathrm{~m}$ for the catalyst concerned.

The Darcy coefficient $(\lambda)$, which depends on the hydrodynamic regime, was found using the Poiseuille formula [8] for the reactor units of square cross section under laminar flow conditions:

$$
\lambda=\frac{57}{\operatorname{Re}} .
$$

We determined the flow resistance of the AVC-10 granulated catalyst layer, which is used in an industrial purification reactor, in order to compare the developed block catalyst with the industrial one. The calculations of $\Delta \mathrm{P}$ for granular materials were carried out according to the method described elsewhere [9]. The pressure loss for the catalyst layer AVC-10 was found by the following formula:

$$
\Delta \mathrm{P}=\frac{\lambda_{3} \cdot 1 \cdot \omega^{2} \cdot \rho \cdot(1-\varepsilon)^{2} \cdot \varphi_{\oplus}}{\mathrm{d}_{3} \cdot 2 \cdot \mathrm{g} \cdot \varepsilon^{3}}
$$

where $\varepsilon$ is the fractional free volume (fr. unit).

The results of the calculations of reactors parameters for the developed catalyst blocks in comparison with industrial rectors for AVC-10 are given in Table 4.

\section{Conclusions}

The obtained data showed that the developed plate catalyst has a lower flow resistance than the industrial granulated catalyst AVC-10. To unify the presented data, they were recounted for a catalyst layer with $1 \mathrm{~m}$ length. Thus, flow resistance of catalyst block installed in a cylindrical reactor was 12 times lower, and the resistance of block in rectangular reactor was 23 times lower than those typical of catalyst AVC-10. This allows significantly reducing the energy costs for compressors to make overpressure for pumping the gas mixture through the reactor.

\section{REFERENCES}

1. Ispolzovanie plazmennoi tekhnologii pri sozdanii katalizatorov na nositelyakh / Rutkovskiy A.E., Vishnyakov L.R., Chehovskiy A.A., Kirkun N.I. // Poroshkovaya metallurgiya. 2000. - No. 3-4. - P.116-119.

2. Shukis P.J., Carruthers J.D., Lostaglio V.J. Process for forming high activity catalysts. Patent of the United States. No. 6239066 B1. - 2001.

3. Issledovanie vliyaniya tekhnologii prigotovleniya katalizatora na raspredilenie kataliticheski aktivnogo veschestva po poverkhnosti nositelya / Loboyko A., Vekshin V., Markova N., Vorozbiyan M., Shapareva L. // Suchasni problemi tekhnologii neorganichnykh rechovkn. - 2008. - No. 2(10). - P.59-62.

4. Sposib vygotovlennya blochnogo katalizatora ochystky vykydnykh gaziv vid oksydiv nitrogenu / Loboyko O.I., Hryn H.I., Vekshin V.O., Markova N.B., Bahrova I.V., Mykysha H.V. // Patent of Ukraine - No. 90106 U. - 2014.

5. Vorobiev A.K. Diffuzionnye zadachi v khimicheskoi kinetike. - M.: Izd-vo Mosk. un-ta, 2003. - 98 p.

6. Vetoshkin A.G. Protsessy i apparaty gazoochistki. Pemza: Izd-vo PGU, 2006. - 201 p.

7. Mikhalev M.A. Gidravlicheskii raschet napornykh truboprovodov // Inzhenerno-stroitelnyi zhurnal. - 2012. No. 6. - P.20-28.

8. Kasatkin A.G. Osnovnye protsessy i apparaty khimicheskoi tekhnologii. - M.: Goskhimizdat, 1961. - 829 p.

9. Protsessy i apparaty khimicheskoi tekhnologii / Tovazhnyanskiy L.L., Gotlinskaya A.P., Leschenko V.A., Nechiporenko I.A., Chernyshov I.S. - Kharkov: NTU «KhPI», 2004. $-1176 \mathrm{p}$.

Received 03.09.2019 


\section{ТЕХНІЧНА ХАРАКТЕРИСТИКА СТІЛЬНИКОВОГО КАТАЛІЗАТОРА ВІДНОВЛЕННЯ ОКСИДІВ НІТРОГЕНУ (II), (IV) ТА РОЗРАХУНОК РЕАКТОРА ДЛЯ НЬОГО}

\section{В.О. Векиин, С.Р. Грабовецька, Л.П. Абрамова}

Розглянуто методику розрахунку промислових реакторів для металевих каталізаторів стільникової структури, які пропонується використовувати в процесах низькотемпературного очищення викидних газів від оксидів Нітрогену за допомогою аміаку. Показані переваги каталітичних блоків в порівнянні із сучасними промисловими каталізаторами АВК-10. Наведено методику здійснення фізико-хімічних досліджень та аналітичного контролю. На основі лабораторних випробувань визначені розміри та розроблено конструкцію запропонованих реакторів. Для двох типів реакторів - з квадратним і круглим перерізом - розраховано необхідну кількість каталізатора у вигляді металевих блоків стільникової структури. Визначено довжину каталітичних блоків $і$ запропоновано технологію їх виробництва. На основі гідродинамічних розрахунків з'ясовано, що блочні каталізатори мають більш низький гідравлічний опір, порівняно з гранульованими. Показано, що для реакторів круглого перерізу потрібні каталітичні блоки меншого об'єму, ніж для квадратних, проте остаостанні мають наднизький гідравлічний опір газовому потоку. Здійснені дослідження показали, що застосування металевих каталітичних блоків стільникового типу дозволить відмовитись від необхідності використання додаткових компресорів створення надлишкового тиску для продування газів крізь шар каталізатора, що має знизити економічні витрати, та, врешті решт, привести до зменшення собівартості продукту.

Ключові слова: оксиди, носій, каталізатор, реактор, очищення, Нітроген, структура.

\section{TECHNICAL CHARACTERISTICS OF A CELLULAR CATALYST FOR THE REDUCTION OF NITROGEN (II) AND (IV) OXIDES AND DESIGN OF A SUITABLE REACTOR}

V.A. Vekshyn ${ }^{a,}{ }^{*}$, E.R. Grabovetskaya ${ }^{b}$, L.P. Abramova ${ }^{a}$

a Kharkiv National Medical University, Kharkiv, Ukraine, b V.N. Karazin Kharkiv National University, Kharkiv, Ukraine * e-mail: myposta2014@gmail.com

The method of the designing of industrial reactors with metal cellular catalysts is considered in the article. The proposed catalysts can be used for the low-temperature purification of exhaust gases from nitrogen oxides using ammonia. The advantages of catalytic blocks are shown in comparison with the catalysts $A V C-10$ that is widely used in industry. The procedures of physicochemical study and analytical control are developed. Based on laboratory tests, the sizes and structure of the proposed reactors are determined. Required amount of catalyst in the form of metal cellular blocks is determined for two types of reactors: with rectangular and circular cross-sections. The length of catalytic units is calculated and production technology is proposed. Hydrodynamic calculations demonstrate that block catalysts have lower flow resistance that the granulated ones. The reactors of circular cross-section need catalytic units of smaller volume than rectangular ones; however, the latter have a lower resistance to gas flow. The study shows that the metal cellular catalytic blocks would allow avoiding the use of additional compressors for excessive pressure to purge gases through the catalyst bed, which should reduce economic costs, and, ultimately, reduce the cost of the product.

Keywords: oxide; carrier; catalyst; reactor; purification; nitrogen; structure.

\section{REFERENCES}

1. Rutkovskiy A.E., Vishnyakov L.R., Chehovskiy A.A., Kirkun N.I. Ispolzovanie plazmennoi tekhnologii pri sozdanii katalizatorov na nositel'yakh [The use of plasma processing for the development of catalysts on carriers]. Poroshkovaya Metallurgiya, 2000, no. 3-4, pp. 116-119. (in Russian).

2. Shukis P.J., Carruthers J.D., Lostaglio V.J., Process for forming high activity catalysts. Patent US, no. 6239066 B1, 2001.

3. Loboyko A., Vekshin V., Markova N., Vorozbiyan M., Shapareva L. Issledovanie vliyaniya tekhnologii prigotovleniya katalizatora na raspredilenie kataliticheski aktivnogo veschestva po poverkhnosti nositelya [Investigation of the effect of the preparation of a catalyst on the distribution of catalytic active substance on the surface of a carrier]. Suchasni Problemy Tekhnologiyi Neorganichnykh Rechovyn, 2008, no. 2(10), pp. 5962. (in Russian).

4. Loboyko O.I., Hryn H.I., Vekshin V.O., Markova N.B., Bahrova I.V., Mykysha H.V., Sposib vygotovlenn'ya blochnogo katalizatora ochystky vykydnykh gaziv vid oksydiv nitrogenu [The fabrication of block catalysts for the purification of end gases from nitrogen oxides]. Patent UA, no. 90106, 2014. (in Ukrainian).

5. Vorobiev A.K., Diffuzionnye zadachi v khimicheskoi kinetike [Diffusion problems in chemical kinetics]. Moscow State University Publishers, Moscow, 2003. 98 p. (in Russian).

6. Vetoshkin A.G., Protsessy $i$ apparaty gazoochistki [Processes and apparatus for gas purification]. PGU Publishers, Pemza, 2006. 201 p. (in Russian).

7. Mikhalev M.A., Gidravlicheskii raschet napornykh truboprovodov [Hydraulic calculation of pressure pipelines]. Inzhenerno-Stroitelnyi Zhurnal, 2012, no. 6, pp. 20-28. (in Russian).

8. Kasatkin A.G., Osnovnye protsessy i apparaty khimicheskoi tekhnologii [Main processes and apparatus in chemical engineering]. Goskhimizdat Publishers, Moscow, 1961. 829 p. (in Russian).

9. Tovazhnyanskiy L.L., Gotlinskaya A.P., Leschenko V.A., Nechiporenko I.A., Chernyshov I.S., Protsessy $i$ apparaty khimicheskoi tekhnologii [Processes and apparatus in chemical engineering]. NTU «KhPI» Publishers, Kharkiv, 2004. 1176 p. (in Russian). 